\title{
Cytogenesis of the Human Fetal Pancreas'
}

JAMES L. CONKLIN

Department of Anatomy, University of Michigan, Ann Arbor, Michigan

The initial survey of pancreatic islet formation in the human fetus was reported by Pearce ('03) who described the development of the islets from the primitive pancreatic tubules. The islets were first identifiable in a $54 \mathrm{~mm}$ fetus as clusters of small eosinophilic cells attached to the tubule but following vascularization, as observed in a $90 \mathrm{~mm}$ fetus, they became separated from the tubules by an encroachment of connective tissue. Studies by Seyfarth ('20) and Nakamura ('24) confirmed the origin of the islets but differed from Pearce in that they found the first islets in 50 and $80 \mathrm{~mm}$ fetuses, respectively.

The occurrence of two cell types in the fetal islet was initially reported by Weichselbaum and Kryle ('09) while Kardasewitch ('27) described two cell types within the duct system of a $45 \mathrm{~mm}$ fetus. The first indication of islet development was noted by Kardasewitch in a $60 \mathrm{~mm}$ fetus when small darkly stained cells, the "Insulocytes," began to proliferate but "typical" islets were not observed until the $90 \mathrm{~mm}$ stage.

Neubert ('27) also described the development of islet cells from ductule epithelium and, in addition, from cells located at the terminal ends of the ducts. These cells contained intensely stained granules and exhibited a "muddy" appearance which was typical of all young islet cells. Furthermore, such scattered isletpotential cells were always found on the outer surface of groups of cells arranged around adjacent blood vessels, a grouping referred to by Neubert as an "Inselfeld."

In a more recent study of the fetal pancreas, Ferner and Stoeckenius ('51) divided islet development into three stages: (a) single cells, (b) "Inselfeld," and (c) "Mantelinsel." The first stage, observed in a $130 \mathrm{~mm}$ fetus, consisted of alpha cells within the walls and terminal proc- esses of the duct system and beta cells within the walls of the intercalated ducts and terminal processes. These alpha cells were considered to be the "muddy" cells previously described by Neubert ('27). Beta cells were not as numerous as alpha cells and always appeared in close proximity to the blood capillaries.

In the "Inselfeld" stage, single or small groups of cells had accumulated to form islet processes. These islet processes contained alpha and beta cells and also a rosecolored cell with ungranulated cytoplasm. In the "Mantelinsel" stage, the beta cells were present as a core within the islet and were surrounded by the rose-colored cells which were, in turn, enclosed within a shell of peripherally located alpha cells. The intermediate zone of the islet was considered by Ferner and Stoeckenius to be an area of transformation in which the alpha cells lost granules and acquired the characteristics of the beta cells, since some of the rose-colored cells contained a few alpha granules and others contained a few beta granules.

In contrast to the numerous reports of islet development in the human fetus, there have been few studies concerned with the development of the pancreatic acini. The first account is that of Neubert ('27) who described the geometrical development of the acini but did not, however, describe the staining characteristics of the acinar epithelium. Several investigators have made cursory observations on the time of appearance of the acinar cells. These include the presence of acini in a $25 \mathrm{~mm}$ embryo (Kardasewitch, '27), a $42 \mathrm{~mm}$ fetus (Lewis, '12) and in a fetus of nine weeks (Leigner, '32).

Although there is general agreement regarding the mode of development of the

1 This research was supported, in part, by Predoctoral Fellowship CF-7515-C2, National Cancer Health Service. 
pancreatic parenchyma, there is obvious lack of agreement as to the stages at which the developmental events occur. In addition, the description of Ferner and Stoeckenius ('51) of the conversion of one cell type into another differs from the reports of other investigators. One of the reasons for these discrepancies may be the variety of staining methods employed, many of which were nonspecific or only partially selective. These techniques included picric acid and eosin or safranin (Pearce, '03), differential solubility (Lane, '07), neutral gentian and acid fuchsin (Bensley, '15), Mallory-azan (Bloom, '31), and chrom alum hematoxylin and phloxine (Gomori, "41; Ferner and Stoeckenius, '51). The most selective staining method thus far developed for the demonstration of all islet cell types, i.e., aldehyde fuchsin (Gomori, '50) and Masson trichrome (Masson, '29) has not been previously employed in a study of the development of the pancreatic islets of the human fetus.

The present study was undertaken in an attempt to describe the sequential development of the parenchyma of the human pancreas employing the aldehyde fuchsin and Masson trichrome techniques and other contemporary histochemical methods. Particular attention was directed toward the histochemical differentiation of both islet and acinar tissues in order to (a) describe the process of cellular maturation and (b) to determine the time of development of the several cell types.

\section{MATERIALS AND METHODS}

The tissues employed in this study consisted of samples of pancreata from 54 human fetuses ranging in size from 29 $\mathrm{mm}$ to approximately $360 \mathrm{~mm}$ crownrump length. ${ }^{2}$ This size range corresponds to the eighth week through the thirtyninth week of fetal development (Patten, '53). The specimens were fixed in either $10 \%$ neutral buffered formalin, Bouin's fluid, or Zenker-formol. After paraffin or celloidin-paraffin embedding, the tissue sections were subjected to the following staining procedures: hematoxylin and eosin or the Masson trichrome method, (Masson, '29) for routine histology; aldehyde fuchsin (Gomori, '50), Masson A and light green as a distinguishing stain for the beta, alpha and delta cells of the pancreatic islets; periodic acid Schiff and colloidal iron (Mowry, '58), controlled by digestion with diastase, for identifying glycogen, neutral and acid mucopolysaccharides; methylene blue buffered to $\mathrm{pH}$ 5.6 , controlled by digestion with ribonuclease, for the demonstration of ribonucleic acid; Bodian's protargol procedure (Lillie, '54) for revealing argyrophilic cells; the dimethylaminobenzaldehyde technique (Adams, '57) for the staining of tryptophan containing proteins; the AltmannMasson procedure (Severinghaus and Thompson, '39) for demonstrating mitochondria; incubation in naphthol-AS-acetate and garnet GBC (Gomori, '52) for exhibiting nonspecific esterase activity.

In the description which follows the specimens have been arbitrarily divided into several selected age groups which are expressed in terms of crown-rump length. This grouping was done in order to facilitate description and has no developmental significance.

\section{RESULTS}

The dorsal and ventral anlagen of the pancreas have fused prior to the onset of the fetal period. However, the tissues derived from each of the anlagen can be distinguished by their relationship to the portal vein. There are no apparent differences between the parenchymal derivatives of the dual primordia at any stage of development.

At the beginning of the fetal period (circa $30 \mathrm{~mm} \mathrm{CR}$ ), the pancreatic parenchyma consists of a system of multibranched epithelial tubules which terminate distally either as solid cords or as small clumps of cells (fig. 1). The latter will be referred to as cell buds since, as will be described, they utimately give rise to both acinar and islet epithelium. Mitotic figures are numerous in the cell buds and in the terminal cell cords and less numerous throughout the remainder of the tubule system. The tubules (fig. 2)

\footnotetext{
2 Generously made available from the Embryological Research Collection of the Department of Anatomy, The University of Michigan Medical School, and from the Wenner-Gren Cardiovascular Research Institute, Stockholm, Sweden, through the courtesy of Doctors Alexander Barry; Jonathan T. Lanman, and John Lind, respectively.
} 
are composed of moderately eosinophilic cuboidal cells which contain small, intensely basophilic nuclei. Acidophilic connective tissue fibers enclose the tubules while the sparse intertubular stromal fibers are argyrophilic.

30-65 mm CR (8-11 weeks). Throughout this phase of the fetal period, there is an increase in the number of epithelial buds at many sites along the duct system. Early in the period, certain of the cell buds along the course of the tubule system (paratubular cell buds) and also some of the terminal cell buds gradually acquire a basophilic cytoplasm. In addition, the nuclei of these cells are less intensely stained and consequently nucleoli are distinguishable. Nucleoli are not visible in the duct epithelium at this stage and the nuclei are darkly stained. Also at this time, distinctive cell types become apparent with the appearance of argyrophilic cells in the pancreata of $\mathrm{fe}$ tuses of about $30 \mathrm{~mm} \mathrm{CR}$ length. These argyrophilic cells are located in the paratubular cell buds (fig. 3) but are not present in the terminal cell buds or within the walls of the tubules. Later in this period, about $55 \mathrm{~mm} \mathrm{CR}$, an occasional cell of the paratubular cell buds contains a few small Masson A positive granules diffusely scattered throughout its cytoplasm. These cells, which are considered to be alpha cells, are most numerous in those cell buds located within the head of the pancreas and less frequent in other areas of the organ.

65-90 $\mathrm{mm} C R$ (11-12.5 weeks). The tubules of the pancreas have an arborous ype of origin but in their distal course sxhibit a parallel arrangement. The inerval between adjacent tubules is filled sy a loose stroma of argyrophilic fibers ind an extensive capillary network whose orimary branches form plexuses around he tubules. The cell buds increase in ize by cellular proliferation and, by the and of the period, paratubular cell buds rom adjacent tubules begin to merge with :ach other. Many of these expanding cell ruds grow toward capillaries within the troma and as the buds undergo fusion, is observed in an $85 \mathrm{~mm}$ fetus, the capilaries become enveloped within a mass f cells. This gives rise to the configura- tion of a cordlike cluster of cells penetrated by a capillary bed and corresponds to the "Inselfeld" stage of Neubert ('27).

Argyrophilic cells are now present in some of the terminal cell buds although still most abundant in the paratubular cell buds. Alpha cells are much more numerous and are present in the walls of the tubules and the terminal cell buds, in addition to the paratubular cell buds. These alpha cells are ovoid, about $20 \mu$ in diameter, with light gray cytoplasm that contains numerous, red staining granules. The nuclei are large and contain prominent particles of chromatin and several large nucleoli. The alpha cell granules also stain positively after the dimethylaminobenzaldehyde (DMAB) technique (fig. 4).

Another distinctive cell type appears in the cell buds during the early part of this period. This cell, ranging in size from 15 to $22 \mu$ in diameter, has a large nucleus, an occasional nucleolus, and finely granular cytoplasm. Since the cytoplasm demonstrates affinity for light green, this is considered to be the delta cell. The remaining cells of the cell buds are the smaller basophilic cells which were previously described. Near the end of the period, about $85 \mathrm{~mm} \mathrm{CR}$, many of the small cells of the cell buds stain simultaneously with aldehyde fuchsin and light green with the result that the cytoplasm is colored a pale gray and has a muddy appearance (fig. 5).

90-110 $\mathrm{mm}$ CR (12.5-14.5 weeks). The parenchyma has become organized into lobes and lobules (fig. 6) and the various parts of the duct system can be distinguished. The lobar ducts (fig. 7) consist of tall columnar cells while the intralobular ducts (fig. 8) are composed of a low columnar or cuboidal epithelium. The epithelium of the intercalated ducts (fig. 9) is either low cuboidal or simple squamous. The cytoplasm of all the duct cells is lightly eosinophilic while the nuclei are large and variably contain nucleoli.

During this period, many of the terminal duct cells assume the acinar arrangement typical of the adult pancreas. The cells enlarge, become pyramidal in shape, and are grouped around a central 
lumen. In a few of the acini intercalated duct cells become partially enclosed by acinar cells thus giving rise to centroacinar cells. The nuclei of the acinar cells are large, vesicular and contain prominent nucleoli while the cytoplasm has a muddy appearance after staining with aldehyde fuchsin and light green.

Glycogen is present in moderate amounts in the large duct cells (figs. 10 and 11). It increases in the smaller duct cells and is present in large amounts in the acinar cell buds (fig. 12). Islet cell buds are prominent by the absence of glycogen (fig. 13).

Initially, the islets contain four cell types, i.e., argyrophilic, alpha, delta and nongranular (presumably immature) cells while later in the period the most prevalent islet cell types are alpha and delta cells. However, while the alpha cells continue to increase the delta cells are observed to gradually decline and simultaneously cells appear which have a dark green cytoplasm that contains very fine aldehyde fuchsin positive granules. A short time later some of the largest islets contain cells, approximately $25 \mu$ in diameter, which possess coarse cytoplasmic granules that are stained by aldehyde fuchsin or colloidal iron (fig. 14). These cells have distinctive, large, vesicular nuclei and large nucleoli and are considered to be beta cells. By the end of the period, many beta cells are evident and some of the islets demonstrate the "Mantelinsel" configuration (fig. 15) described by Ferner and Stoeckenius ('51). Typically, the beta cells lie in the center of the islet surrounded by other cell types. The argyrophilic and alpha cells lie in the peripheral area of the islet while the delta and immature beta cells lie either within the beta cell core or at the junction with the alpha cell layer. A small number of ungranulated, immature cells are scattered throughout the islet. Scattered beta cells are also present in the walls of the intralobular and intercalated ducts (fig. 16).

The basement membranes of the tubules and the connective tissue capsules of the islets are acidophilic and PAS and colloidal iron positive. The fibers of the intertubular stroma are no longer argyrophilic, stain lightly with acid dyes, and exhibit a slight affinity for either aldehyde fuchsin or colloidal iron.

110-150 $\mathrm{mm}$ CR (14.5-17 weeks). During this stage, the acinar epithelia demonstrate the greatest change. The entire cytoplasm of these cells becomes intensely basophilic but gradually the basophilia becomes most prominent in the basal areas of cell (fig. 17). Shortly thereafter small granules appear in the basal cytoplasm which are DMAB positive (fig. 18) and exhibit nonspecific esterase activity (fig. 19) similar to the zymogen granules of the adult. As the zymogen granules become more numerous and increase in size, the largest granules accumulate in the apical cytoplasm. Although most of the acini contain zymogen granules by the end of this stage, few of the cells exhibit the density of granulation characteristic of the adult acinar cell. Despite the accumulation of zymogen granules, the acinar cells still contain a large quantity of glycogen which is concentrated in the apical cytoplasm. Long filamentous mitochondria are evenly distributed throughout the cytoplasm of these cells.

The mitochondria of the islet cells are more variable in number and size. The beta cells usually contain many, fine granular mitochondria (fig. 20) while those of the alpha cells are similar but not as numerous. The delta cells differ conspicuously since they contain few, very small mitochondria (fig. 21).

Midway through the period, the granules of some beta cells become aggregated in the cytoplasm adjacent to blood capillaries and an occasional cell is observed which appears to be degranulated. Later in the period, the alpha cells are observed to undergo similar morphological changes.

The intertubular connective tissue fi. bers no longer stain with aldehyde fuchsir. but are acidophilic and PAS and colloida] iron positive similar to the peritubular base. ment membranes.

150-210 $\mathrm{mm}$ CR (17-22 weeks). Ir addition to their localization in the islets alpha, beta and delta cells are still presen in a few of the intralobular and inter calated ducts. Their presence in the lat ter sites is thought to indicate continuec 
formation of islet cell buds since these cells occasionally are in mitosis.

Glycogen begins to disappear from the intralobular duct epithelium early in the period and is completely absent from 190 $\mathrm{mm}$ specimens. In addition, the glycogen of the intercalated ducts and acini slowly decreases and, except for a few scattered droplets, is absent in the $200 \mathrm{~mm}$ fetus. The acinar zymogen granules continue to increase and by the $210 \mathrm{~mm}$ stage many of the acini are filled with esterase positive granules (fig. 22).

Early in the period, the islets begin to lose the "Mantelinsel" configuration. This occurs by fusion of adjacent islets with the result that the various cell types become randomly dispersed throughout the islet. In fetuses of $160 \mathrm{~mm} \mathrm{CR}$, many of the alpha cells are degranulated and there is a concomitant increase in the number of argyrophilic cells. The argyrophils remain elevated until midway through the period when they decline and alpha cells are again more numerous. After this the number of argyrophils remains low and only an occasional such cell is present in the islets.

There is a continued increase in both the number of degranulated beta cells and in the number of beta cells which exhibit polarization of cytoplasmic granules around the islet capillaries. This appears to occur in a cyclic manner with the result that one islet will contain a preponderance of degranulated cells (fig. 23) while in an adjacent islet all of the beta cells well be either partially or completely filled with granules (fig. 24). Immature epithelial cells continue to be present in the islets. The islet cells are only lightly basophilic (fig. 25) with the beta cell exhibiting the most intensely basophilic cytoplasm.

Thin connective tissue septa separate the various lobules and the sparse intralobular connective tissue consists mainly of fibers which surround the acini, islets and ducts.

$360 \mathrm{~mm}$ CR (39 weeks). The acinar tissue has increased and the intercalated ducts are much less prominent than before. The islets are larger and more prominent than in the adult organ, and very few of them are of the "Mantelinsel" type.
None of the earlier stages of islet formation are observed, i.e., the "Inselfeld" stage or "single cell" stage and although a few immature cells are present within the islets no mature islet cell types are found in any part of the duct system. However, many of the islets are still attached to the duct system by a cord of small, nongranular epithelial cells. The morphology of the various cell types is as previously described.

\section{DISCUSSION}

As noted by previous investigators, both the acinar and islet epithelia develop from the primitive pancreatic tubules. These tubules branch repeatedly and give rise to an arborescent duct system from which small groups of cells proliferate to form islet and acinar cell buds.

The tubular epithelium exhibits the least alteration of any of the parenchyma. The cytoplasm of these cells remains lightly acidophilic and except for changes in the nuclei, the primary change is in the size and shape of the cells. This involves an enlargement of the cells of the lobar ducts and an apparent decrease in size in the cells which form the intercalated ducts. The nuclear changes, which occur near the end of the third month, consist of a decrease in nuclear basophilia and an enlargement of the nucleoli.

The most striking characteristic of the tubular epithelium of the fetal period is the glycogen which is present from late in the third month to the end of the fifth month (circa 70-200 mm CR). The exact time of appearance of glycogen was not determined with certainty because of the lack of mercuric-fixed tissues prior to the third month. Glycogen could not be demonstrated in formalin or Bouin's fixed material prior to this stage, however, but could be demonstrated in such material at subsequent stages. It is doubtful therefore, that it was present in any quantity prior to the period indicated. Disappearance of glycogen was observed to occur in a progressive fashion so that it was lost from the lobar ducts, then from the intralobular and intercalated ducts, and last of all from the terminal cell buds. The same type of progression was noted by Sorokin, Padykula and Herman ('59) in 
the fetal lung and was considered to be a reflection of the maturity of the cells, i.e., the more primitive epithelium contained the most glycogen. This probably accounts for the early disappearance of glycogen from the presumptive islet cells and indicates the later maturation of the tubule and acinar epithelium. This does not explain completely, however, the persistence of glycogen in the acinar epithelium after the appearance of mature zymogen granules, although more subtle metabolic changes may be more closely related to the maturation of these cells.

The cells which will produce islet tissue are recognizable late in the second month by the accumulation of cytoplasmic ribonucleic acid and the prominence of nucleoli and probably correspond to the "Insulocytes" of Kardasewitch ('27). They are located in cell buds which are derived directly from the primitive tubules in contrast to cell buds which later originate from intralobular and intercalated ducts. While some authors (Simard, '37; Bencosme, '55; Mori and Haga, '60) have designated the difference in derivation of cell buds as primary and secondary islet formation, this seems to be an unnecessary distinction. The mature islets appear to be the same regardless of origin and the difference in derivation is probably only another indication of the progressive maturation of the tubule epithelium.

As the islet cell buds increase in size, they grow into the intertubular stroma and the cells become intimately associated with blood capillaries. This stage of development was referred to as the "Inselfeld" by Neubert ('27) and Ferner and Stoeckenius ('51). Seyfarth ('20) suggested that the islets exerted an inductive effect on acinar development. Although this could not be determined in the present study, it is true that the islets do appear before the acini and always lie near the center of the lobule surrounded by acinar tissue.

The "Mantelinsel" stage described by Ferner and Stoeckenius was said to persist until the fourth postnatal year. In the present study this stage was predominant only during the fifth fetal month and the adult type was most common thereafter. While Pearce ('03) reported that the islets lost their attachment to the tubule epithe- lium, it was observed that many of the islets were still attached to the intercalated ducts at the end of the fetal period.

All of the cells of the immature islet cell buds are intensely basophilic but after the appearance of specific cell types, only the beta cells continue to be moderately basophilic.

The first distinctive islet cell to appear is the argyrophilic cell. This cell is probably an intermediate in the formation of the alpha cell as suggested by Ferner and Stoeckenius ('51) Hultquist and Thorell ('53) and Bencosme ('55). The argyrophilic cell appears just before the alpha cell, is found in the same location as the alpha cell, and there is a reciprocal relationship between the numbers of these cells, i.e., as the alpha cells become more numerous the argyrophilic cells decrease. Also, the staining characteristics of these two cells are suggestive of such a relationship. The argyrophilic cells, which are also argentaffinic, are DMAB negative while the alpha cells are DMAB positive. Since the argentaffin reaction is demonstrated by aminophenols, among other phenolic compounds (Pearse, '60), the argentaffin granules may consist of tryptophan precursors such as hydroxyanthranilate or hydroxykynurenine. These substances would be expected to exhibit an affinity for silver while the tryptophan of the alpha cell granules would not. The acidophilia of the alpha cell granules is probably due to the many free amino groups of glucagon.

Although Ferner and Stoeckenius ('51) suggested that the delta cell was a degenerative type, evidence has been obtained in the present study which suggest that this cell is intermediate in the formation of the beta cell. First, the delta cells appear slightly before the beta cells are apparent. Secondly, prior to the appearance of the latter, acidophilic cells are observed which contain small aldehyde fuchsin-positive cytoplasmic granules. It is thought, in agreement with Munger ('58), that these are the "muddy" cells described by Neubert ('27) and Bencosme ('55) and not alpha cells as sug. gested by Ferner and Stoeckenius ('51). Finally, the distribution of the delta cells 
within the "Mantelinsel" is similar to the distribution of the beta cells.

Although Ferner and Stoeckenius ('51) reported the transformation of alpha into beta cells, no evidence for such a transformation was observed in the present study. The transformation zone which they described in the "Mantelinsel" consists primarily of immature epithelial cells which develop into either alpha or beta cells. Mature islet cells are also produced by mitotic division of existing alpha, delta and beta cells.

The order of appearance of the pancreatic islet cells of the human fetus differs from that observed in other species. In the rat (Hard, '44), rabbit (Bencosme, '55) and mouse (Munger, '58; Mori and Haga, '60), the beta cells appear before the alpha cells. In the present study, the argyrophilic cell was present at the end of the second month ( $30 \mathrm{~mm} \mathrm{CR}$ ), followed by the alpha cell in the middle of the third month ( $50 \mathrm{~mm} \mathrm{CR}$ ), the delta cell slightly later and the beta cell early in the fourth month ( $85 \mathrm{~mm} \mathrm{CR}$ ) of the fetal period. Although Kardasewitch ('27) and Pearce ('03) placed the development of islets after acinar formation, the islets begin to develop in the second month while acinar cells do not appear before the end of the third month. This difference in observation is probably due to the difficulty in distinguishing between islets and acinar cell buds when specific stains are not employed.

The first indications of maturation of the acinar epithelium are the affinity of the cytoplasm for aldehyde fuchsin, the enlargement of the nucleoli and a decrease in nuclear basophilia. The latter events undoubtedly reflect an alteration in nucleic acid metabolism since it is shortly after this that the cytoplasm becomes intensely basophilic. Following the accumulation of cytoplasmic ribonucleic acid, cytoplasmic granules appear which exhibit nonspecific esterase activity and contain demonstrable tryptophan, both of which are characteristic of the mature acinar zymogen granules.

No evidence of secretory activity by the acinar epithelium was observed although the cells seem fully capable of secretion from the fifth month onward. Of the islet cells, only the beta cell appears to secrete during the fetal period. From the end of the fourth month ( $130 \mathrm{~mm} \mathrm{CR}$ ) to term, beta cells were observed which offered morphological evidence suggestive of secretory activity. The alpha cells offered transitory evidence of secretion during the early part of the fifth month but did not appear to be active after this time. In studies of other species (Hard, '44; Bencosme, '55; Munger, '58) it was observed that the alpha cells did not function during the fetal period, in fact, did not develop until several days after birth.

There does not seem to be any correlation between the onset of secretory activity of the islet cells in the human fetus and the beginning of secretory activity of other endocrine glands. According to Gillman ('48) the follicles of the thyroid gland contain colloid by the eighth week while chromophil cells are present in the pars distalis by the ninth week. Also, according to Gillman, the adrenal cortex offers evidence of hormone production in the ninth week and has the capacity for cortisol biosynthesis by the twelfth week (Bloch and Benirschke, '59). This capacity for secretion by the other glands does correspond to the beginning of islet cell maturation.

Several changes were noted in the stroma of the pancreas which provide information about the maturation of the stromal fibers. Reticular fibers are the predominant type until about the eighth week of development when the fibers which enclose the parenchymal elements acquire the staining characteristics of collagenous fibers. The intertubular fibers remain reticular-like until the end of the third month when they cease to be argyrophilic and stain very lightly with aldehyde fuchsin and colloidal iron. By the end of the fourth month they no longer stain with aldehyde fuchsin, are acidophilic and PAS and colloidal iron positive. These changes probably reflect changes in the ground substance during the maturation of the precollagenous fibers.

The merging of islets with ganglia was described by Neubert ('27) and confirmed by Simard ('37) who suggested the term, neuroinsular complex, to describe ganglia which contained beta cells. Bencosme 
('55) also reported having observed these structures but their existence has been questioned by Coupland ('58) and Munger ('58). Neuroinsular complexes were not observed in the present study and although many of the ganglia are in close proximity to both islets and acini, there seemed to be a well defined connective tissue capsule separating the parenchyma from the ganglia.

\section{SUMMARY}

The sequential development of the human fetal pancreas has been investigated by histochemical methods.

The pancreatic islets are initially derived from the primitive pancreatic tubules and secondarily from the intralobular and intercalated ducts. In addition, islet growth is supplemented by mitotic division of mature islet cell types.

The islet cells develop sequentially, with the argyrophilic cell appearing during the eighth week of development, followed by the alpha, delta and beta cells during the tenth, eleventh and thirteenth weeks, respectively. The argyrophilic cell is considered to be an intermediate in the formation of the alpha cell while the delta cell is thought to be a precursor or intermediate of the beta cell. The alpha and beta cells are fixed cell types and transformation of one type to the other was not observed.

From the end of the fourth month until term, the beta cells exhibit morphological evidence of secretory activity. The alpha cells offer only transitory indications of secretory activity early in the fifth month.

Glycogen is present in the duct epithelium and acini during a part of their development but is absent from the islets at all stages.

The pancreatic acini differentiate from the cells at the terminal ends of the intercalated ducts. The first indication of acinar differentiation is an apparent alteration in nucleic acid metabolism. This is followed by the appearance of zymogen granules which possess the characteristics of those observed in the adult pancreas.

Although zymogen granules are present, the acini offer no evidence of secretory activity during the fetal period.

\section{ACKNOWLEDGMENTS}

The author is indebted to Doctors Alexander Barry and Burton $L$. Baker for advice and encouragement and to Miss Mary Silvester for technical assistance.

\section{LITERATURE CITED}

Adams, C. W. M. 1957 A p-dimethylaminobenzaldehyde-nitrite method for the histochemical demonstration of tryptophane and related compounds. J. Clin. Path., 10: 56-62.

Bencosme, S. A. 1955 The histogenesis and cytology of the pancreatic islets in the rabbit. Am. J. Anat., 96: 103-151.

Bensley, R. R. 1915 Structures and relationships of the islets of Langerhans. Harvey Lect., 10: 250-289.

Bloch, E., and K. Benirschke 1959 Synthesis in vitro of steroids by human fetal adrenal gland slices. J. Biol. Chem., 234: 1085-1089.

Bloom, W. 1931 A new type of granular cell in the islets of Langerhans of man. Anat. Rec., 49: 363-371.

Coupland, R. E. 1958 The innervation of pancreas of rat, cat and rabbit as revealed by the cholinesterase technique. J. Anat., 92: 143149.

Ferner, H., and W. Stoeckenius, Jr. 1951 Die Cytogenese des Inselsystems beim Menschen. Ztschr. f. Zellforsch. u. mikr. Anat., 35: 147175.

Gillman, J. 1948 The development of the gonads in man, with a consideration of the role of fetal endocrines and the histogenesis of ovarian tumors. Contrib. Embryol., 32: 81132. (Carnegie Inst. Wash. Pub. No. 210.)

Gomori, G. 1941 Observations with differential stains on human islets of Langerhans. Am. J. Path., 17: 395-406.

- 1950 Aldehyde-fuchsin: A new stain for elastic tissue. Am. J. Clin. Path., 20: 665666.

1952 Microscopic Histochemistry. University of Chicago Press, Chicago.

Hard, W. I. 1944 The origin and differentiation of the alpha and beta cells in the pancreatic islet of the rat. Am. J. Anat., 73: 369403.

Hultquist, G. T., and B. Thorell 1953 Cytological changes during the embryonal formation of Langerhan's islands as revealed by ultraviolet microscopy. Acta path. et. microbiol. Scandinav., 32: 245-250.

Kardasewitch, B. I. 1927 Embryologie der Langerhansschen Inseln des menschlichen Pankreas. Ztschr. f. d. ges. Anat., 83: 793803.

Lane, M. A. 1907 The cytological characters of the areas of Langerhans. Am. J. Anat., 7: $709-722$.

Leigner, B. 1932 Studien zur Entwicklung des Pankreas, besonders der Langerhansschen Inseln. Ztschr. f. mikr.-anat. Forsch., 30: 494529.

Lewis, F. T. 1912 The early development of the entodermal tract and the formation of its subdivisions. In: Keibel, F. and F. P. Mall, 
eds., Manual of Human Embryology. J. B. Lippincott Co., vol., 2, Pp. 295-334.

Lillie, R. D. 1954 Histopathologic Technic and Practical Histochemistry, 2nd ed. The Blakiston Company, Inc., New York.

Masson, P. 1929 Some histological methods: Trichrome stainings and their preliminary technique. J. Techn. Methods, 12: 75-90.

Mori, T., and A. Haga 1960 Histological and histochemical observations on the developing pancreas of fetal mouse. Tohoku J. Exper. Med., 72: 42-58.

Mowry, R. W. 1958 Improved procedure for the staining of acidic polysaccharides by Muller's colloidal (hydrous) ferric oxide and its combination with the Feulgen and the periodic acid-Schiff reactions. Lab. Invest., 7: 566-576.

Munger, B. L. 1958 A light and electron microscopic study of cellular differentiation in the pancreatic islets of the mouse. Am. J. Anat., 103: 275-311.

Nakamura, N. 1924 Untersuchungen über das Pankreas bei Föten, Neugeborenen, Kindern und im Pubertätsalter. Arch. path. Anat., 253: 286-348.

Neubert, K. 1927 Bau und Entwicklung des menschlichen Pankreas. Arch f. Entwicklingsmechn. d. Organ., 111: 29-118.
Patten, B. M. 1953 Human Embryology. 2nd ed. The Blakiston Company, Inc., New York.

Pearce, R. M. 1903 The development of the islands of Langerhans in the human embryo. Am. J. Anat., 2: 445-455.

Pearse, A. G. E. 1960 Histochemistry, 2nd ed. Little, Brown and Co., Boston.

Severinghaus, A. E., and K. W. Thompson 1939 Cytological changes induced in the hypophysis by the prolonged administration of pituitary extract. Am. J. Path., 15: 391-412.

Seyfarth, C. 1920 Neue Beiträge zur Kenntnis der Langerhansschen Inseln im menschlichen Pankreas und ihre Beziehung zum Diabetes mellitus. Gustav Fischer, Jena.

Simard, L. C. 1937 Les complexes neuro-insulaires du pancreas humain (Neurocrinie et fonction paraganglionnaire). Arch. anat. micr., 33: 49-64.

Sorokin, S., H. A. Padykula and E. Herman 1959 Comparative histochemical patterns in developing mammalian lungs. Develop. Biol., 1: $125-151$.

Weichselbaum, A., and J. Kryle 1909 Über das Verhalten der Langerhansschen Inseln des menschlichen Pankreas im fötalen und postfötalen Leben. Arch. f. Mikr. Anat., 74: 223258. 
PLATE 1

\section{EXPLANATION OF FIGURES}

1 Parenchymal cell buds (B) in the pancreas of a $30 \mathrm{~mm} \mathrm{CR}$ fetus. Hematoxylin and eosin. $\times 75$.

2 The pancreatic tubules of a $30 \mathrm{~mm}$ CR fetus. The nuclei of the tubular cells are small and intensely basophilic. Hematoxylin and eosin. $\times 125$.

3 Argyrophilic cells within paratubular cell buds of a $30 \mathrm{~mm}$ CR fetus. Protargol. $\times 250$.

4 Alpha cells (A) within an islet as demonstrated by the dimethylaminobenzaldehyde technique. $\times 400$.

5 "Muddy" cells $(M)$ in the parenchyma of an $85 \mathrm{~mm} \mathrm{CR}$ fetus. Aldehyde fuchsin, Masson A and light green. $\times 250$.

6 A pancreatic lobule. The intralobular duct (D) is centrally located while islets (I) are encircled by developing acini. Aldehyde fuchsin, Masson $A$ and light green. $\times 75$.

7 A pancreatic lobar duct. The duct epithelial cells are lightly stained and enclosed within an aggregation of acidophilic connective tissue fibers. Aldehyde fuchsin, Masson $A$ and light green. $\times 400$.

8 A pancreatic intralobular duct. Aldehyde fuchsin, Masson A and light green. $\times 400$.

9 A pancreatic intercalated duct. The outer perimeter of the duct has been outlined in ink. This duct and the intralobular duct are enclosed by a thin basement membrane. Aldehyde fuchsin, Masson $A$ and light green. $\times 400$.

10 Glycogen in an intralobular and intercalated duct of a $100 \mathrm{~mm} \mathrm{CR}$ fetus. Colloidal iron and periodic acid-Schiff (PAS). $\times 250$.

11 Diastase control. Colloidal iron and PAS. $\times 250$.

12 Glycogen in the acini of a $110 \mathrm{~mm} \mathrm{CR}$ fetus. Only the connective tissue fibers are PAS positive in the adjacent islet (I). Colloidal iron and PAS. $\times 250$. 

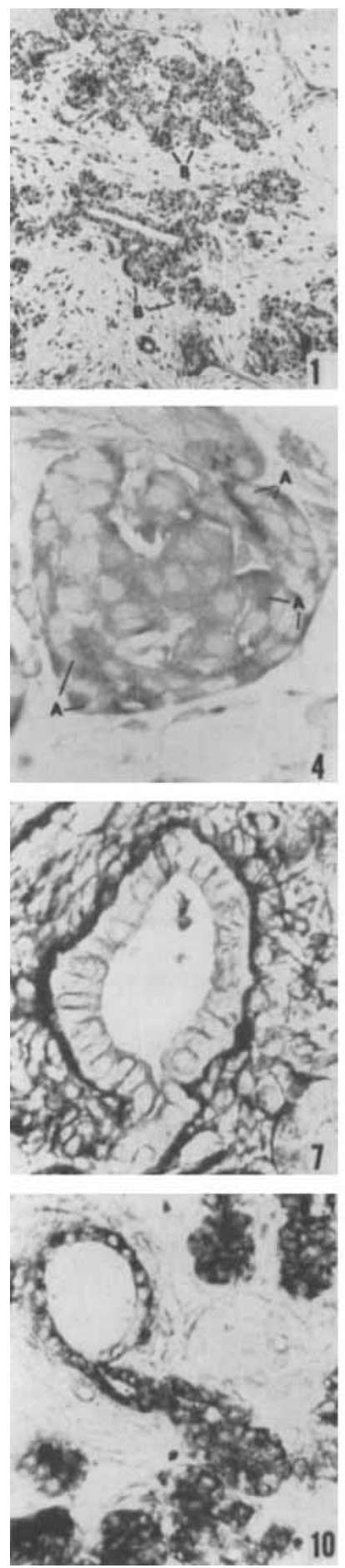
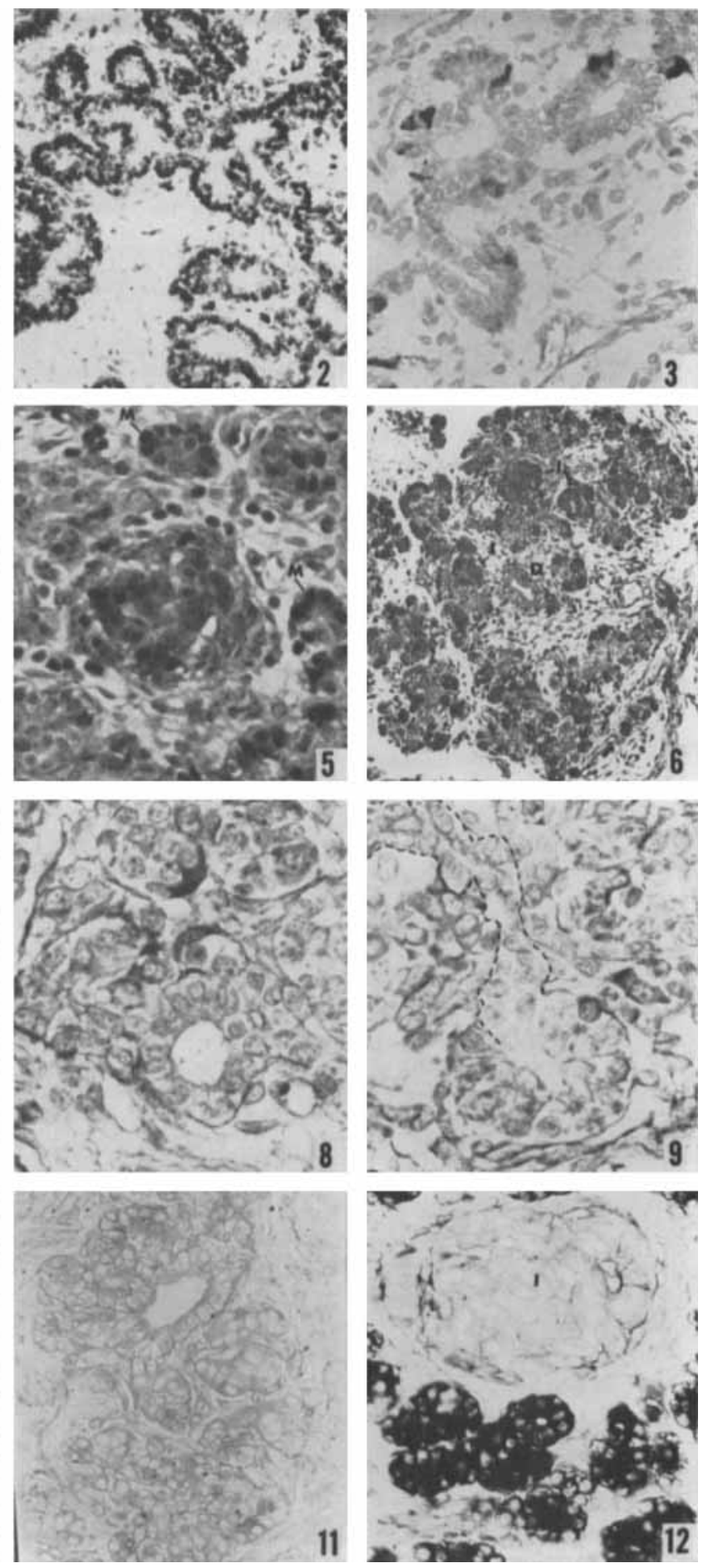


\section{PLATE 2}

\section{EXPLANATION OF FIGURES}

13 An islet (I) and islet cell bud (B) of a $110 \mathrm{~mm} \mathrm{CR}$ fetus. Note the absence of glycogen in these structures. Colloidal iron and PAS. $\times 250$.

14 Beta cells in an islet of a $100 \mathrm{~mm}$ CR fetus. Aldehyde fuchsin, Masson $\mathrm{A}$ and light green. $\times 650$.

15 A "Mantelinsel" in the pancreas of a $110 \mathrm{~mm}$ fetus. The beta cells (darkly stained) are centrally located and surrounded by other islet cell types. Aldehyde fuchsin, Masson $A$ and light green. $\times 250$.

16 A beta cell (B) in the wall of an intralobular duct. Beta cells are also visible in an islet cell bud (lower left). Aldehyde fuchsin, Masson $\mathrm{A}$ and light green. $\times 250$.

17 Basophilia in the basal region of the acinar cells. The nucleoli are also prominently stained. Methylene blue. $\times 400$.

18 The demonstration of tryptophane in the acinar zymogen granules. Demethylaminobenzaldehyde technique. $\times 250$.

19 Nonspecific esterase activity in the acinar epithelia. Small granules first appear in the basal area (G) and then aggregate in the apical cytoplasm. Naphthol-AS-acetate and garnet GBC. $\times 650$.

20-21 Mitochondria in the beta cell (B) and delta cell (D). Altmann acid fuchsin and light green. $\times 650$.

22 Nonspecific esterase activity in the acini of a $210 \mathrm{~mm}$ fetus. Naphol-AS-acetate and garnet GBC, $\times 650$.

23 Degranulated beta cells (B) in a fetal islet. Granule-containing beta cells are present at the lower right. The photograph is taken through the area of contact of two merging islets (dashed line). Aldehyde fuchsin, Masson $\mathrm{A}$ and light green. $\times 650$.

24 Partially degranulated beta cells. Note the accumulation of cytoplasmic granules adjacent to the capillaries (C). Aldehyde fuchsin, Masson $A$ and light green. $\times 650$.

25 Lightly basophilic beta cells (B) in a fetal islet. Only the nucleoli are prominently stained. Methylene blue. $\times 400$. 

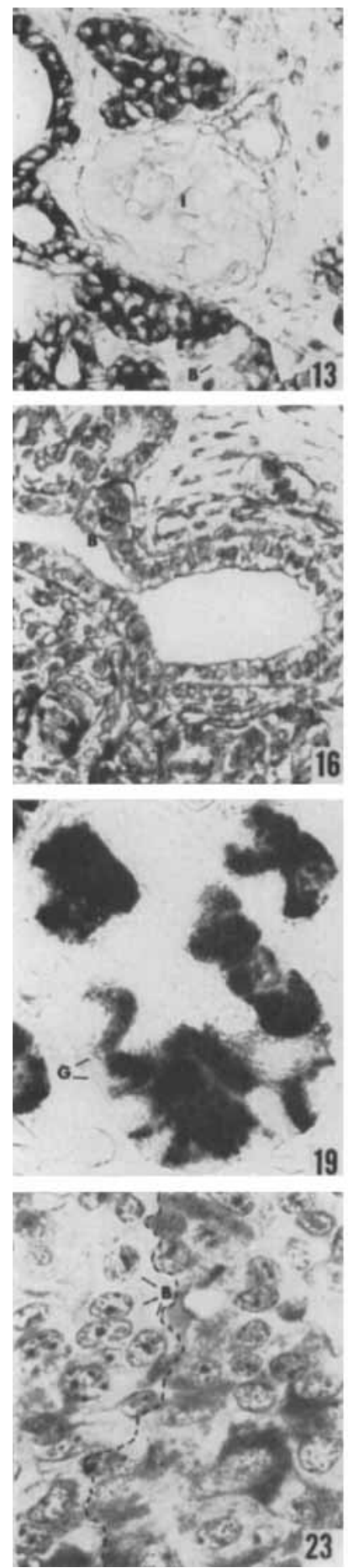

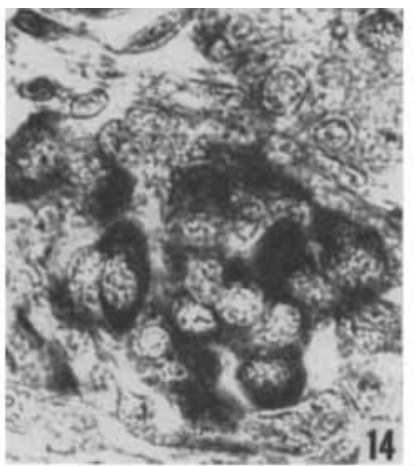

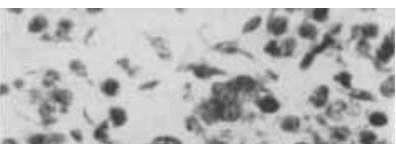

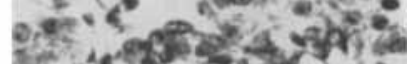

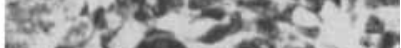

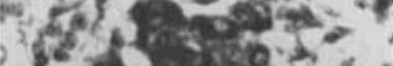

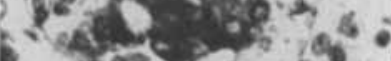
c teranos.

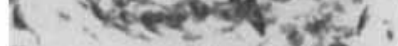
$6=3$ is ${ }^{\circ}{ }^{\circ},{ }^{\circ}$ 8. $1500=0, \quad 15$
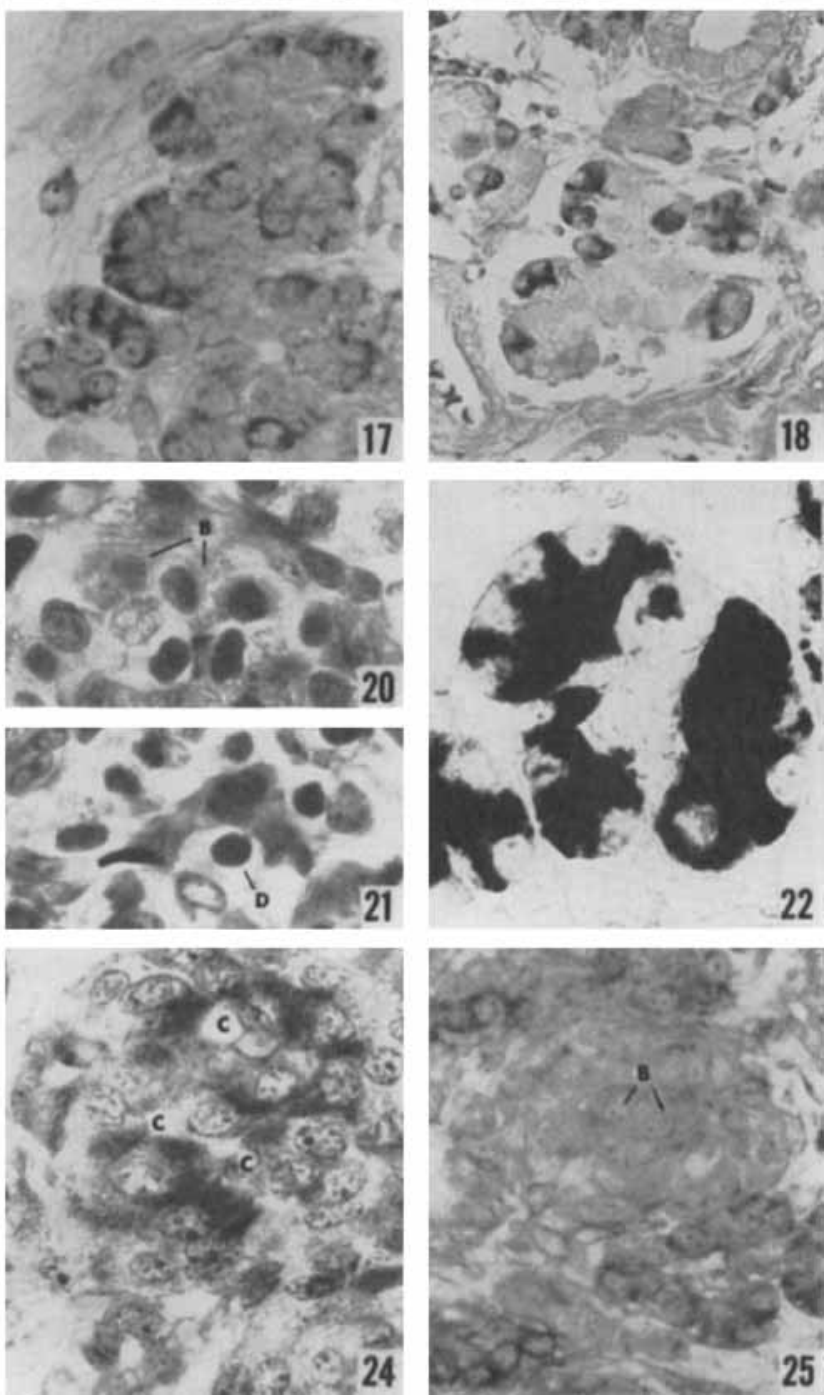